\title{
Closed Incisional Negative Pressure Wound Therapy at Flap Suture Line: An Innovative Approach for Improving Outcomes in Suboptimal Wound Conditions
}

\author{
Ravikiran Naalla $\quad$ Smriti Bhushan ${ }^{1} \quad$ Minhaj Ul Abedin ${ }^{1} \quad$ Ashish Dhanraj Bichpuriya ${ }^{1} \quad$ Maneesh Singhal ${ }^{1}$ \\ ${ }^{1}$ Department of Plastic Reconstructive \& Burns Surgery, All India \\ Institute of Medical Sciences, New Delhi, India \\ Address for correspondence Maneesh Singhal, MCh, FRCS (Glasg), \\ Department of Plastic Reconstructive \& Burns Surgery, All India \\ Institute of Medical Sciences, Plastic Surgery Office, 5th floor, Teaching \\ block, New Delhi 110029, India (e-mail: drmaneesh@gmail.com).
}

Indian J Plast Surg 2020;53:90-96

\begin{abstract}
Keywords

- closed incisional negative pressure wound therapy

- wound healing

- wound dehiscence

Background Persistent dead space following flap cover is a frequently encountered challenge following the reconstruction of complex wounds. It may lead to a hematoma, seroma, wound infection, and wound dehiscence. Wound dehiscence could be a devastating complication. Closed incisional negative pressure wound therapy (ciNPWT) over the surgical incisions was found to reduce surgical site infection (SSI) and wound dehiscence. We applied this principle at the closed flap suture line and through this article, we share the indications, technique, and outcomes.

Methods A retrospective analysis (January 2018-June 2019), in which selected highrisk patients who underwent ciNPWT at the flap suture following complex reconstruction (pedicled or free flap) were included in the study. The indications include deep incisional/organ SSI after debridement and flap coverage, persistent dead space following flap coverage, chronic osteomyelitis. Patients were analyzed in the follow-up period in terms of complications, wound healing.

Results Nine patients underwent ciNPWT over the flap suture line. The mean age was 32.2 years (range: $10-48$ years). The mean duration of the NPWT application was 7.3 days (range: $3-21$ days). Three of the nine patients had flap-related minor complications. One patient had marginal flap necrosis and required skin grafting, one patient had minor wound dehiscence $(1 \mathrm{~cm})$ which required secondary skin suturing and one patient had chronic discharging sinus related to osteomyelitis of ischium, which subsequently healed with antibiotics and local wound care. None of the patients had NPWT-related complications.

Conclusion Closed incisional NPWT decreases the untoward effects of dead space following the reconstruction of complex wounds. The incidence of SSI and wound gaping can be reduced.
\end{abstract}

\section{Introduction}

Flaps play a crucial role in the wound healing of critical wounds in which implants, bone, neurovascular structure, or vital viscera are exposed. Persistent dead space following flap cover is a frequently encountered challenge. It may lead to a hematoma, seroma, wound infection, and wound dehiscence. Wound dehiscence may be a devastating complication. Wound dehiscence in the postoperative period is an published online April 8, 2020
DOI https://doi.org/

10.1055/s-0040-1709528 ISSN 0970-0358.
(C)2020 Association of Plastic

Surgeons of India
License terms

(요 (1) $\odot \circledast$ 
important outcome measure since it impacts the mortality, morbidity, duration of hospital stay. ${ }^{1}$ Despite proper surgical technique, patient comorbidities play a significant role in wound dehiscence. ${ }^{2}$ Surgical site infection (SSI), anemia, hypoproteinemia, tobacco abuse, diabetes are few of the important suboptimal wound factors which contribute to wound dehiscence. ${ }^{1}$

In selected cases like exposed vascular anastomosis/ exposed vital structures, complete optimization of patient's comorbidities might not be possible before contemplating a flap cover. In these cases, wound gaping would be a disastrous complication. Closed incisional negative pressure wound therapy (ciNPWT) has been well described for groin wounds following vascular surgeries, ${ }^{3}$ knee and hip arthroplasties, ${ }^{4}$ abdominoplasty incisions, ${ }^{5}$ breast surgeries, ${ }^{6}$ and abdominal wall reconstruction, ${ }^{7}$ morbidly obese woman following cesarean section. ${ }^{8}$ To the best of our knowledge application of ciNPWT at flap suture line following soft tissue reconstructive surgery has not been described previously. In this article, we share our indications and techniques and outcomes with the ciNPWT.

\section{Materials and Methods}

A retrospective analysis (January 2018-June 2019) of patients who underwent ciNPWT at the flap suture line was included in the study. Selected high-risk patients who underwent complex reconstruction (pedicled or free flap) were included in the study. The indications include patients with soft tissue defects and underlying deep incisional/organ SSI, persistent dead space following flap coverage, chronic osteomyelitis. Patients in whom NPWT was used for relieving flap congestion were excluded from the study.

Patients also underwent initial debridement and appropriate antibiotic therapy before flap coverage. NPWT was either applied in the operation theater immediately after the flap procedure or within 24 to 48 hours following the procedure. NPWT was applied for patients in whom we anticipated complications of persistent dead space/wound drainage at the recipient site in spite of an appropriate flap cover. The suspicion of dead space was based on clinical examination. Whenever the volume of flap was falling short of the defect's volume, a persistent dead space was diagnosed. Other indications are tabulated in - Table $\mathbf{1}$. The recipient site wound was closed completely with the flap cover in all the patients. The skin suturing was done with longer intervals $(1.5-2 \mathrm{~cm})$ to facilitate the effect of NPWT. A 2 to $3 \mathrm{~cm}$ wide sponge was cut and applied over the entire suture line adjacent to the flap and connected to the device set at continuous $-100 \mathrm{~mm} \mathrm{Hg}$ pressure. In a patient in whom flap cover was done over the repaired femoral artery, the pressure was set at $-50 \mathrm{~mm} \mathrm{Hg}$ as described by Berger et al. ${ }^{9}$ This method allows flap monitoring through the transparent adhesive dressing. The dressing is changed after 3 to 4 days. NPWT dressing was reapplied if there was a suspicion of persistent dead space or edematous flap/surrounding skin. In one of the patients, NPWT was continued for 3 weeks because of persistent lymphorrhea from the groin wound following femoral artery repair. Once the NPWT was discontinued, regular dressings were done.

\section{Results}

Nine patients underwent ciNPWT over the flap suture line. The mean age was 32.2 years (range: $10-48$ years). Details of the patients and etiology, critical issues, and duration of treatment and outcome are tabulated in - Table $\mathbf{1}$. The mean duration of the NPWT application was 7.3 days (range: 3-21 days). None of the patients had major complications. Three of the nine patients had flap-related minor complications. One patient had marginal flap necrosis and required skin grafting, one patient had minor wound dehiscence $(1 \mathrm{~cm})$ and required secondary skin suturing and one patient had chronic discharging sinus related to osteomyelitis of ischium, which subsequently healed with antibiotics and local wound care. None of the patients had NPWT-related complications such as hemorrhage and infection.

\section{Case Examples}

- Patient 2: A 35-year-old male patient sustained traumatic right open pneumothorax and was referred to us for management of soft tissue defect over the right chest wall and underlying rib osteomyelitis, empyema, and exposed lung parenchyma. Following debridement ipsilateral pedicled latissimus dorsi myocutaneous flap was done to obliterate the dead space and simultaneous soft tissue cover. The skin and subcutaneous tissues were edematous due to underlying infection. Though a larger flap would have avoided the tension at the suture line, we felt it would be cumbersome to skin graft at the flap donor site in the background of rib osteomyelitis. Following the application of the ciNPWT, the tension at the suture line gradually decreased and the surrounding edema improved in 6 days. The flap settled well and the patient had uneventful recovery ( - Fig. $\mathbf{1})$.

- Patient 3: A 10-year-old child was referred for management of wound over the thoracolumbar region. The patient earlier had spinal instrumentation for scoliosis. The child had SSI and underwent debridement of the necrosed paraspinal muscles and soft tissue. The spinous processes were osteomyelitic and there was dead space around the implant and spinous processes. He underwent V-Y trapezius myocutaneous flap on the left side, bipedicle trapezius myocutaneous flap and pedicled latissimus dorsi myocutaneous flap on the right side. Closed incisional NPWT was applied for 8 days. This helped in reduced need of dressing changes in the postoperative period and untoward effects of dead space and SSI. The postoperative stay was uneventful ( - Fig. 2).

- Patient 4: A 45-year-old male patient underwent contralateral anterolateral thigh flap for coverage of exposed femoral artery repair in the right groin. Challenges in this patient were, an infected wound bed with dead space and persistent lymphorrhea. In the second postoperative day, ciNPWT was applied at the flap suture line and continued for 3 weeks. Gradually the exudate had come down. This 
Table 1 Table showing details of patients

\begin{tabular}{|c|c|c|c|c|c|c|c|}
\hline Patient & Etiology & Diagnosis & $\begin{array}{l}\text { Anatomical } \\
\text { location }\end{array}$ & Flap & Critical issue & $\begin{array}{l}\text { No. of } \\
\text { days of } \\
\text { NPWT }^{a}\end{array}$ & Outcome \\
\hline 1. & $\begin{array}{l}\text { Traumatic } \\
\text { paraplegia }\end{array}$ & Sacral pressure ulcer & Sacral region & $\begin{array}{l}\text { Bilateral fas- } \\
\text { ciocutaneous } \\
\text { hatchet flap. }\end{array}$ & $\begin{array}{l}\text { - Dead space, } \\
\text { - SSI }\end{array}$ & 8 & Good \\
\hline 2. & Trauma & $\begin{array}{l}\text { Open pneumothorax } \\
\text { with osteomyelitis } \\
\text { and segmental loss of } \\
\text { ribs. Empyema tho- } \\
\text { racic with exposed } \\
\text { lung parenchyma. }\end{array}$ & $\begin{array}{l}\text { Right } \\
\text { hemithorax }\end{array}$ & $\begin{array}{l}\text { Right pedicled } \\
\text { myocutane- } \\
\text { ous latissimus } \\
\text { dorsi flap }\end{array}$ & $\begin{array}{l}\text { - Dead space, } \\
\text { - SSI, } \\
\text { - Edematous } \\
\text { surrounding skin. }\end{array}$ & 6 & Good \\
\hline 3. & Scoliosis & $\begin{array}{l}\text { Exposed spinal } \\
\text { implant following } \\
\text { scoliosis correction. }\end{array}$ & Back & $\begin{array}{l}\text { Bilateral } \\
\text { myocutane- } \\
\text { ous trapezius } \\
\text { flap, latissi- } \\
\text { mus dorsi flap }\end{array}$ & $\begin{array}{l}\text { - Dead space, } \\
\text { - Vertebral } \\
\text { osteomyelitis, } \\
\text { - Maintenance } \\
\text { of postoperative } \\
\text { position. }\end{array}$ & 8 & Good \\
\hline 4. & Trauma & $\begin{array}{l}\text { Exposed interposition } \\
\text { vein graft following } \\
\text { repair of femoral } \\
\text { artery with large } \\
\text { soft-tissue defect, } \\
\text { pelvic fracture. }\end{array}$ & Right groin & $\begin{array}{l}\text { Contralateral } \\
\text { Pedicled } \\
\text { myocutane- } \\
\text { ous anterolat- } \\
\text { eral thigh flap }\end{array}$ & $\begin{array}{l}\text { - Exposed } \\
\text { interposition vein } \\
\text { graft, } \\
\text { - Dead space, } \\
\text { - SSI } \\
\text { - Lymphorrhea. }\end{array}$ & 21 & $\begin{array}{l}\text { Marginal flap } \\
\text { necrosis. }\end{array}$ \\
\hline 5. & Trauma & $\begin{array}{l}\text { Exposed implant } \\
\text { following fixation of } \\
\text { the iliac fracture. }\end{array}$ & $\begin{array}{l}\text { Sacroiliac } \\
\text { joint region. }\end{array}$ & $\begin{array}{l}\text { Gluteal fasci- } \\
\text { ocutaneous } \\
\text { hatchet flap }\end{array}$ & $\begin{array}{l}\text { - Dead space, } \\
\text { - SSI, } \\
\text { - Effective drainage } \\
\text { of the wound. }\end{array}$ & 4 & $\begin{array}{l}\text { Minor wound } \\
\text { dehiscence } \\
(1 \mathrm{~cm}) .\end{array}$ \\
\hline 6. & $\begin{array}{l}\text { Traumatic } \\
\text { paraplegia }\end{array}$ & $\begin{array}{l}\text { Pressure ulcer over } \\
\text { the sacral region. }\end{array}$ & Sacral region & $\begin{array}{l}\text { Gluteal fasci- } \\
\text { ocutaneous } \\
\text { hatchet flap }\end{array}$ & $\begin{array}{l}\text { - Dead space, } \\
\text { - SSI, } \\
\text { - Effective drainage } \\
\text { of the wound. }\end{array}$ & 4 & Good \\
\hline 7. & Trauma & $\begin{array}{l}\text { Grade IIIB both bone } \\
\text { leg fracture with } \\
\text { osteomyelitis and } \\
\text { gangrenous extensor } \\
\text { compartment } \\
\text { muscles. }\end{array}$ & Right leg & $\begin{array}{l}\text { Free antero- } \\
\text { lateral thigh } \\
\text { flap }\end{array}$ & $\begin{array}{l}\text { - Dead space, } \\
\text { - SSI, } \\
\text { - Osteomyelitis of } \\
\text { tibia. }\end{array}$ & 8 & Good \\
\hline 8. & Trauma & $\begin{array}{l}\text { Soft tissue defect } \\
\text { over the right leg } \\
\text { with loss of exten- } \\
\text { sor compartment } \\
\text { muscles. }\end{array}$ & Right leg & $\begin{array}{l}\text { Peroneal } \\
\text { artery perfo- } \\
\text { rator based } \\
\text { propeller flap }\end{array}$ & $\begin{array}{l}\text { - Dead space } \\
\text { - SSI, } \\
\text { - Edematous } \\
\text { surrounding skin. }\end{array}$ & 4 & Good \\
\hline 9. & $\begin{array}{l}\text { Intramuscular } \\
\text { injection } \\
\text { sequalae }\end{array}$ & $\begin{array}{l}\text { Left hip disarticula- } \\
\text { tion and fillet thigh } \\
\text { flap for the exposed } \\
\text { pelvic bone. }\end{array}$ & Left hip & $\begin{array}{l}\text { Fillet thigh } \\
\text { flap }\end{array}$ & $\begin{array}{l}\text { - Dead space, } \\
\text { - Osteomyelitis of } \\
\text { pelvic bone. }\end{array}$ & 3 & $\begin{array}{l}\text { Chronic dis- } \\
\text { charging sinus } \\
\text { due to osteomy- } \\
\text { elitis of ischium. } \\
\text { Healed by local } \\
\text { wound care. }\end{array}$ \\
\hline
\end{tabular}

${ }^{a} \mathrm{NPWT}$, negative pressure wound therapy.

bSSI, surgical site infection

technique has eliminated the burden of frequent dressing change due to persistent lymphorrhea. There was marginal necrosis at the lower portion of the flap which was debrided and covered with a skin graft. The patient had stable soft tissue cover ( - Fig. $\mathbf{3}$ ).

- Patient 5: A 23-year-old male was referred to us for management of exposed implant following ORIF of pelvic fracture. He underwent a hatchet fasciocutaneous flap for coverage of the soft-tissue defect on the right side and V-Y flap on the left side. Closed incisional NPWT was applied to the flap suture line. After 4 days the NPWT dressing was removed. The patient had 1-cm wound dehiscence at the noncritical area which was managed with secondary skin suturing (-Fig.4).

\section{Discussion}

Conventional NPWT is well-known for its role in the management of most of the open acute and chronic wounds. ${ }^{10}$ The direct benefits of NPWT are: (a) maintaining moist and warm environment for wound healing provided by 

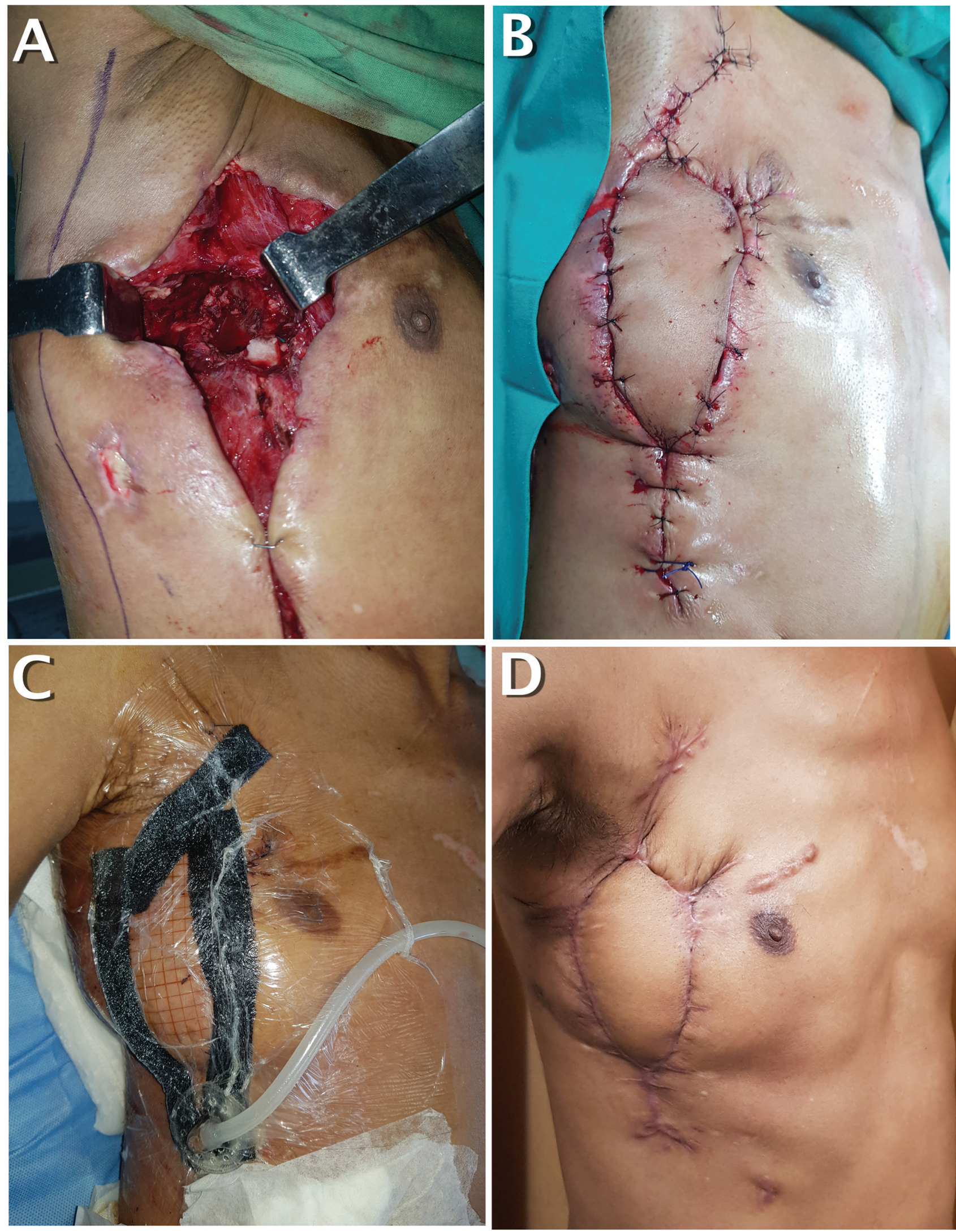

Fig. 1 Image showing (A) right thoracic wound with exposed lung and rib fracture site with osteomyelitis, (B) following debridement and latissimus dorsi myocutaneous flap (the adjacent skin shows gross edema due to prolonged soft tissue inflammation due to underlying infection), (C) NPWT dressing in situ, (D) well-settled flap. NPWT, negative pressure wound therapy. 

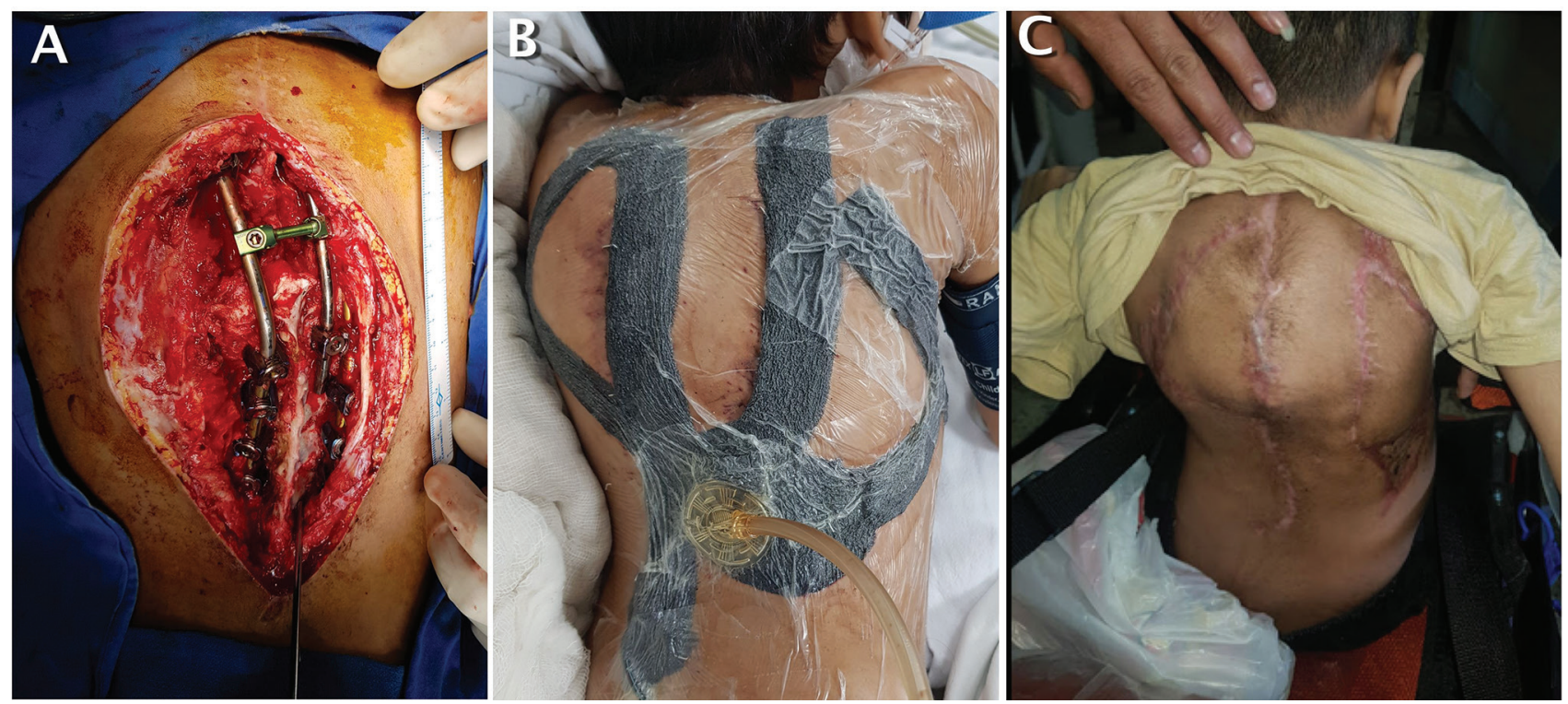

Fig. 2 Image showing (A) wound over the thoracolumbar spine region with exposure of infected spinal implant following scoliosis correction, (B) NPWT dressing following bilateral trapezius flaps and latissimus dorsi myocutaneous flaps, (C) well-settled flaps. NPWT, negative pressure wound therapy.
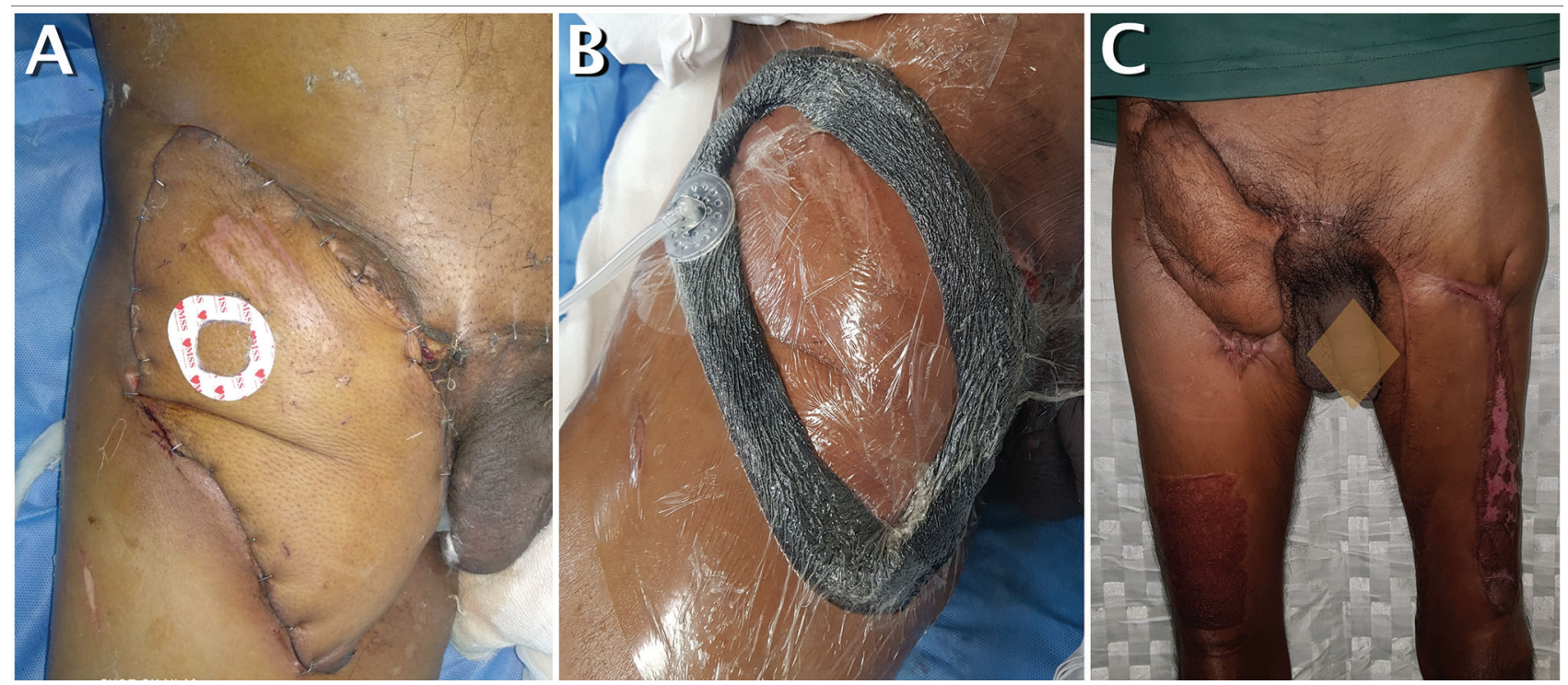

Fig. 3 Image showing (A) contralateral anterolateral thigh flap for exposed femoral artery repair in the right groin. The wound was complicated by surgical site infection and persistent lymphorrhea, (B) NPWT wound dressing in situ, (C) well-settled flap. NPWT, negative pressure wound therapy.

the semipermeable adhesive dressing, (b) reducing wound edema by providing pressure gradient between the wound and the suction canister thereby, draining the fluid from the wound bed and the interstitial space, (c) the wound deformation leads to approximation of the wound edges together, skin graft/flap apposition to the wound bed, (d) the wound dehiscence risk is reduced by reduction of lateral strain at the suture site. ${ }^{11}$ The tissue deformation is also a stimulus for the remodeling of tissues..$^{12}$ The indirect benefits promoting wound healing are augmented blood supply, reduction of inflammation, decreased bacterial burden. ${ }^{13}$

The benefits of ciNPWT on surgical incision were first reported a decade ago. The mechanism of action at the wound site is similar to the conventional NPWT. A recent review article published in the Cochrane database suggests that the ciNPWT has a role in the reduction of SSI in wound healing by primary closure when compared with the conventional wound dressings. ${ }^{14}$

NPWT has shown to be beneficial for closed surgical wounds over the groin following vascular surgeries, ${ }^{15}$ selected patients with risk factors for wound healing complications following knee and hip surgery.${ }^{16}$ Application of NPWT reduced the incidence of SSI following general and colorectal surgeries; however, there was no much difference in terms of seroma and wound dehiscence rates when compared with conventional dressings. ${ }^{17}$ NPWT is also helpful in 


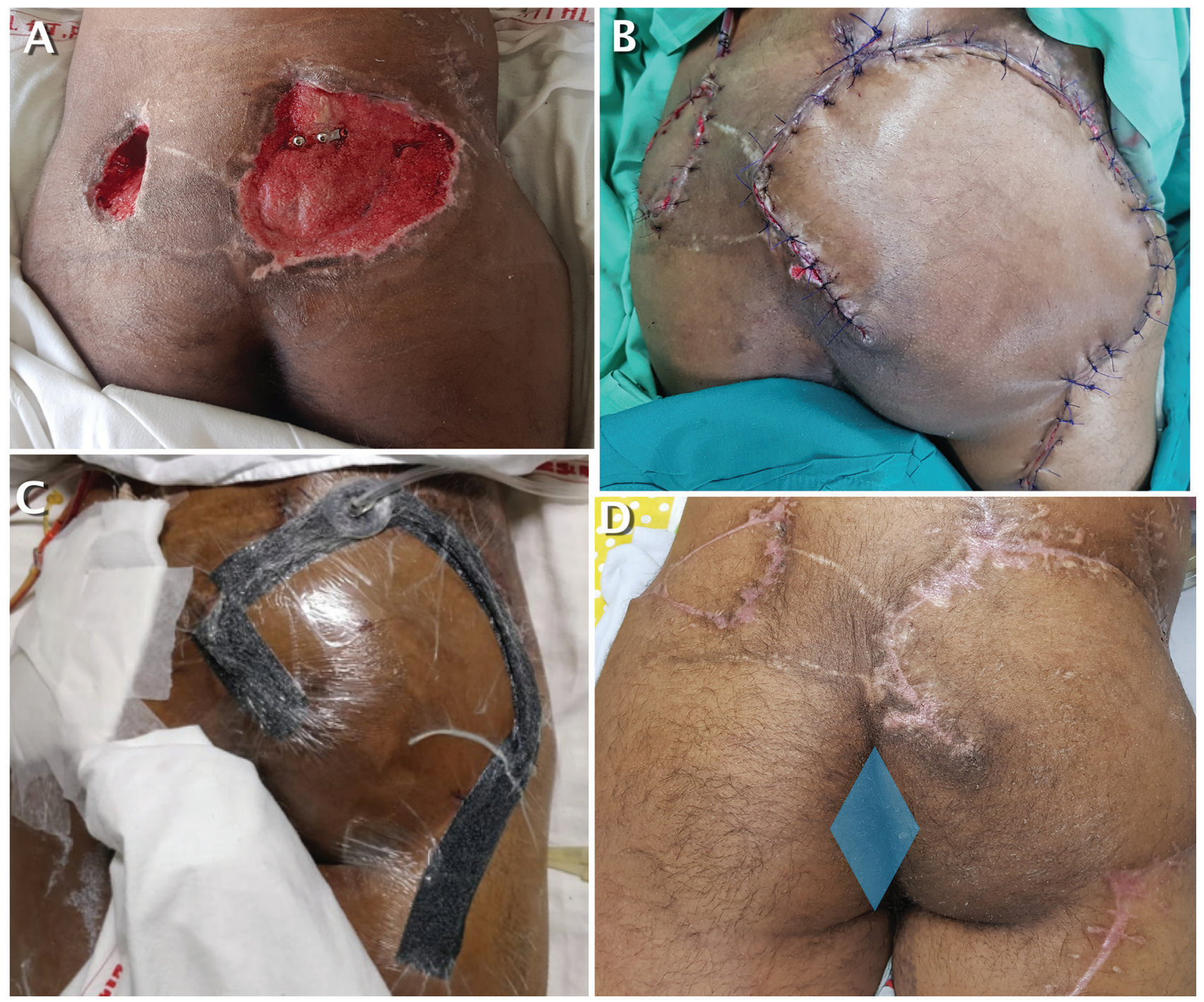

Fig. 4 Image showing (A) exposed implant in the sacral region following ORIF, (B) inset of fasciocutaneous hatchet flap, (C) NPWT dressing in situ, (D) well-settled flap. NPWT, negative pressure wound therapy; ORIF, open reduction with internal fixation.

groin wounds complicated by lymphorrea. ${ }^{18}$ Incisional NPWT has also shown a positive effect on the healing of primarily closed defects of superficial circumflex iliac artery perforator flap harvest. ${ }^{19}$

Role of NPWT in preventing bacterial migration into the wound following cardiac surgery was hypothesized by Grauhan et al. ${ }^{20}$ These advantages of ciNPWT are also helpful in a reconstructive surgeon's practice in complicated wounds after flap cover.

Routine use of ciNPWT is not cost-effective in all patients who undergo flaps. We recommend ciNPWT only in selected cases of complex wound reconstructions in which dead space persists even after flap coverage. The indications can be extended to cases where lateral wound tension is more than usual at the suture site, lymphorrhea at the surgical site, patients with risk factors for SSIs. We have used the conventional polyurethane foam NPWT which is used for open wounds. However, simplified versions of NPWT are also available. These consist of a single-use battery-driven NPWT device with a portable canister. The latter is used for wounds that do not have much exudate in high-risk patients. ${ }^{21}$ The technique we used is much cheaper, easily available, and can be applied in patients with very highly exudating wounds. These are used for single linear incision lines and not manufactured for application around the flap site. Prophylactic ciNPWT has been used in few of our patients (patients 1-3) when we anticipated SSI in high-risk patients. In others (patients 4-9) ciNPWT has been applied in the postoperative period. In this study, we have utilized NPWT over the flap suture line when the flap was still healthy. We did not include the cases where NPWT was utilized for salvage of already compromised flap. When we utilized this technique in the background of osteomyelitis, adequate debridement was already performed before contemplating flap coverage. However, in patient 3 who had osteomyelitis of spine, flap coverage was done to ensure antibiotic delivery and coverage with vascularized tissue. Closed incision NPWT helped in better wound healing by eliminating the risks of persistent dead space following flap coverage. 
The indications of ciNPWT continue to be defined and utilization of this technique at flap suture line has a lot of scope in day to day plastic surgery practice. The limitations of the study are small sample size and lack of a comparison group.

\section{Conclusion}

Closed incisional NPWT at the flap suture line is a useful wound care modality, beneficial in patients who undergo complex wound reconstruction. It decreases the untoward effects of dead space following flap coverage. It is protective against SSI and wound gaping.

\section{Financial Disclosures}

Nil.

\section{Conflict of Interest}

None declared.

\section{References}

1 Shanmugam VK, Fernandez SJ, Evans KK, et al. Postoperative wound dehiscence: predictors and associations. Wound Repair Regen 2015;23(2):184-190

2 van Ramshorst GH, Nieuwenhuizen J, Hop WC, et al. Abdominal wound dehiscence in adults: development and validation of a risk model. World J Surg 2010;34(1):20-27

3 Hasselmann J, Björk J, Svensson-Björk R, Acosta S. Inguinal vascular surgical wound protection by incisional negative pressure wound therapy: a randomized controlled Trial-INVIPS Trial. Ann Surg 2020;27(1):48-53

4 Nam D, Sershon RA, Levine BR, Della Valle CJ. The use of closed incision negative-pressure wound therapy in orthopaedic surgery. J Am Acad Orthop Surg 2018;26(9):295-302

5 Abesamis GM, Chopra S, Vickery K, Deva AK. A comparative trial of incisional negative-pressure wound therapy in abdominoplasty. Plast Reconstr Surg Glob Open 2019;7(5):e2141

6 Matusiak D, Wichtowski M, Pieszko K, Kobylarek D, Murawa D. Is negative-pressure wound therapy beneficial in modern-day breast surgery? Contemp Oncol (Pozn) 2019;23(2):69-73

7 Tran BNN, Johnson AR, Shen C, Lee BT, Lee ES. Closed-incision negative-pressure therapy efficacy in abdominal wall reconstruction in high-risk patients: a meta-analysis. J Surg Res 2019;241:63-71

8 Hussamy DJ, Wortman AC, McIntire DD, Leveno KJ, Casey $\mathrm{BM}$, Roberts SW. Closed incision negative pressure therapy in morbidly obese women undergoing cesarean delivery: a randomized controlled trial. Obstet Gynecol 2019;134(4):781-789

9 Berger P, de Bie D, Moll FL, de Borst GJ. Negative pressure wound therapy on exposed prosthetic vascular grafts in the groin. J Vasc Surg 2012;56(3):714-720

10 Capobianco CM, Zgonis T. An overview of negative pressure wound therapy for the lower extremity. Clin Podiatr Med Surg 2009;26(4):619-631

11 Wilkes RP, Kilpad DV, Zhao Y, Kazala R, McNulty A. Closed incision management with negative pressure wound therapy (CIM): biomechanics. Surg Innov 2012;19(1):67-75

12 Nishimura K, Blume P, Ohgi S, Sumpio BE. Effect of different frequencies of tensile strain on human dermal fibroblast proliferation and survival. Wound Repair Regen 2007;15(5):646-656

13 Mouës CM, Vos MC, van den Bemd GJ, Stijnen T, Hovius SE. Bacterial load in relation to vacuum-assisted closure wound therapy: a prospective randomized trial. Wound Repair Regen 2004;12(1):11-17

14 Webster J, Liu Z, Norman G, et al. Negative pressure wound therapy for surgical wounds healing by primary closure. Cochrane Database Syst Rev 2019;3:CD009261

15 Gombert A, Babilon M, Barbati ME, et al. Closed incision negative pressure therapy reduces surgical site infections in vascular surgery: a prospective randomised trial (AIMS Trial) Eur J Vasc Endovasc Surg 2018;56(3):442-448

16 Giannini S, Mazzotti A, Luciani D, et al. Postoperative wound management with negative pressure wound therapy in knee and hip surgery: a randomised control trial. J Wound Care 2018;27(8):520-525

17 Sahebally SM, McKevitt K, Stephens I, et al. Negative pressure wound therapy for closed laparotomy incisions in general and colorectal surgery: a systematic review and meta-analysis. JAMA Surg 2018;153(11):e183467

18 Abai B, Zickler RW, Pappas PJ, Lal BK, Padberg FT Jr. Lymphorrhea responds to negative pressure wound therapy. J Vasc Surg 2007;45(3):610-613

19 Peter Suh HS, Hong JP. Effects of incisional negative-pressure wound therapy on primary closed defects after superficial Circumflex Iliac artery perforator flap harvest: randomized controlled study. Plast Reconstr Surg 2016;138(6):1333-1340

20 Grauhan O, Navasardyan A, Hofmann M, Müller P, Stein J, Hetzer R. Prevention of poststernotomy wound infections in obese patients by negative pressure wound therapy. J Thorac Cardiovasc Surg 2013;145(5):1387-1392

21 Malmsjö M, Ingemansson R. Effects of green foam, black foam and gauze on contraction, blood flow and pressure delivery to the wound bed in negative pressure wound therapy. J Plast Reconstr Aesthet Surg 2011;64(12):e289-e296 